\title{
Correlation on Students Commitment and Satisfaction in Sekolah Tinggi Ilmu Ekonomi Galileo Batam Indonesia
}

\author{
Hazriyanto $^{1, *}$, Amir Daus ${ }^{2}$, Badaruddin Ibrahim ${ }^{3}$ \\ ${ }^{1}$ Faculty of Economics and Management, STIE Galileo, Indonesia \\ ${ }^{2}$ IAI Ar-Risalah Sungai Guntung, Indonesia \\ ${ }^{3}$ Department of Engineering Education, Faculty of Technical and Vocational Education, Universiti Tun Hussein Onn Malaysia, \\ Malaysia
}

Received June 25, 2019; Revised January 10, 2020; Accepted February 25, 2020

Copyright $\mathrm{C} 2020$ by authors, all rights reserved. Authors agree that this article remains permanently open access under the terms of the Creative Commons Attribution License 4.0 International License

\begin{abstract}
Education at the college level is now supposed to get attention, especially related to the students who are in the college environment. The commitment and satisfaction of students who are in college are beneficial to create a college environment as expected. For that, a study needs to be run to investigate the commitment and satisfaction of students in a college environment, especially in the environment of Sekolah Tinggi Ilmu Ekonomi (STIE) Galileo Batam. Research is given attention to student commitment and satisfaction. This research is a quantitative study involving 33 respondents from students residing in the environment of STIE Galileo. The research aims to investigate the relationship between commitment and satisfaction. The questionnaire is used to collect research data, then in sports with SPSS statistics. Correlation analysis is performed to ensure the relationship between commitment and satisfaction. The correlation test results showed that the relationship of commitment and satisfaction was positive and significant and the relationship is in a strong category. It is necessary to be noticed, and future research should consider other variables that are not explored in this research, such as motivation, environment, and more significant sample quantities and analysis tools such as; SEM SmartPLS and SEM Amos. In addition, future researchers can revisit from a demographic standpoint.
\end{abstract}

Keywords Correlation, Commitment, Satisfaction, Students

\section{Introduction}

At this time, the way in the process of management of the college is a focus of attention, and various programs that exist in the college both Curriculum and Implementation Framework is hoping to realize a system that promotes the involvement of multiple parties in the development of colleges. Therefore, the colleges need to prepare from various aspects of both the involvement and commitment of lecturers, organizers, management systems, and regulations of the colleges. This is to make it easier for the parties involved to have access to involve themselves with the development of colleges. In a great struggle of human resources, this is an essential element when compared with other elements. Therefore, the role of human beings in college is significant and inseparable. The human role determines success in the absence of a goal, and it is said to be essential and decisive in achieving the objectives of the university because the human resources bring the goal to achieve a goal of the organization itself. The performance of employees is the result of work in quality and quantity achieved by an officer in carrying out his duties in accordance with the responsibilities assigned to him.

The development of human resources should be seen as part of common and major purposes but not only the interests of the Government. Human resources should focus on human significance as perpetrators and beneficiaries of the process and achieve development outcomes both for themselves and for the environment. Lecturers and students are expected to improve the quality and self-reliance in resolving the problems faced by them, both individually and in groups in carrying out their duties and responsibilities as lecturers and as Students. For the implementation of the program in accordance with the expectation of the commitment and satisfaction from various parties, especially from lecturers and students, it is 
necessary. The commitment and satisfaction of lecturers and students are expected to be able to make a positive contribution to the development process of higher education.

Commitment is an attitude that illustrates loyalty to the organization, an individual identity that engages actively in an organization, to have a strong desire to stay a member of the organization, to strive to suit the expectations of the organization and to believe and accept certain values and organizational objectives as well as the measures of strength to engage in the purpose and values of the organization (Luthans \& F, 2005). Besides, commitment is the level of confidence and acceptance of workers to the organizational objectives and the desire to always be with the organization (Mathis \& Jackson, 2011).

Meanwhile, job satisfaction is an emotional state in assessing their work. Job satisfaction is an expression of an individual's feelings toward his work. This is evident in his positive attitude toward work and everything faced in his work environment (Hani Handoko, 2010). Job satisfaction is also an emotional attitude demonstrated by workers to the success of their work. This attitude is described by the moral of workers, discipline, and achievement of work (Hasibuan, 2012).

Committed employees will be more likely to have satisfaction so as to achieve maximum work achievement. As the study conducted by Elangovan, (2001) it suggests that there is a strong cause and effect relationship with satisfaction and commitment in Canada. While, the results of the equation of the modeling structure show that the Amanah organization has a direct impact on commitment and job satisfaction and has an indirect effect on both (Fard \& Karimi, 2015).

The commitments of people from private colleges are essential organizational commitments that are proven to increase employees' work satisfaction levels. Researchers have suspected that there is a significant difference between the levels of commitment of private college organizations. It is tested to ensure the truth of this hypothesis. Results show that employees of government colleges have a higher level of commitment compared to private colleges. Satisfaction increased or decreased based on increased or decreased organizational commitments (Adekola, 2012). Findings from other studies have also presented a significant relationship between variables and contributions. The study contributes to the literature and empirical support in improving knowledge of the relationship between satisfaction and the Organization's commitment to Egypt (Rageb, Abd, El-Samadicy, \& Farid, 2013).

The problem identified in this study is:

1. Does commitment have a relationship with satisfaction?

The research aims to:

1. Know the relationship of commitment to satisfaction.

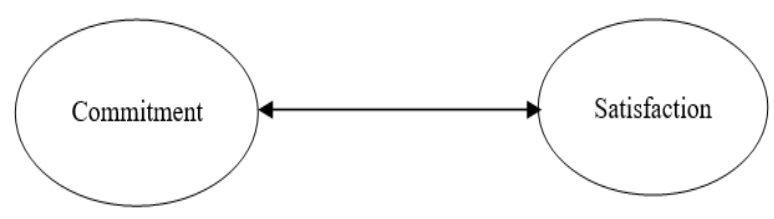

Figure 1. Frameworks of thought

The research hypothesis is:

$\mathrm{H} 1$ : There is a correlation between commitment to satisfaction.

\section{Research Methodology:}

This research was conducted in the STIE Galileo environment within three months from December 2018 to March 2019. Respondents in this study involved the students in the neighborhood of STIE Galileo Batam with a sample of 33 respondents. This type of research is a quantitative study with data collection tools using questionnaires distributed to the students in the environment of STIE Galileo. The collected data was analyzed using SPSS statistics. The research conducted a descriptive frequency analysis of the collected data to investigate the relationship between variables used in the correlation analysis. The data in this research was collected in the high school of the Galileo Economic Sciences located in Batam, Indonesia. The population that exists in this study amounted to 41 students, the Liquid Student Management study program at the Economics Force 2019.

The data collection techniques use the questionnaire with a closing statement and answer with the choice of the Likert scale. The data analysis techniques used are correlation analysis. Data analysis is the validity test and reliability test by spreading the questionnaire to 41 respondents, then performing the data selection that can be used for the analysis process. Out of 41 numbers of the spread questionnaires, there were 33 complete questionnaires so that the data to be processed in this study amounted to 33 respondents. Afterward, a correlation analysis was performed, initiated by conducting a normality test and hypothesized test in Program SPSS version 23.0 .

The variables used in this study are commitment and satisfaction. Instrument item indicator used in the study consists of 13 items for commitment and 16 items for the satisfaction of the adaptation and adapted to the research needs of the results of the Instrument Questionnaire Research (Hazriyanto \& Ibrahim, 2019).

\section{Results and Discussion:}

The respondent's data in this study involves students in STIE Galileo based on the sex of men and women. Table 1 shows the frequency test results. 
Table 1. Frequency Test Results

\begin{tabular}{|c|c|c|c|}
\hline \multicolumn{2}{|c|}{ Gender } & Frequency & Percent \\
\hline \multirow{3}{*}{ Valid } & Man & 17 & 51.5 \\
\cline { 2 - 4 } & Women & 16 & 48.5 \\
\cline { 2 - 4 } & Total & 33 & 100.0 \\
\hline
\end{tabular}

The results of the frequency test in the conducted study involved 17 male students equivalent to $51.5 \%$ and 16 female students equivalent to $48.5 \%$, with the total number of respondents in the study amounting to 33 students. In addition, the respondent's data is based on student status as working in a college or college students. Table 2 shows the frequency test results based on the respondent's status.

Table 2. Frequency Test Results Based on Respondent's Status

\begin{tabular}{|c|c|c|c|}
\hline \multicolumn{2}{|c|}{ Status } & Frequency & Percent \\
\hline \multirow{4}{*}{ Valid } & Student & 3 & 9.1 \\
\cline { 2 - 4 } & Student and Worker & 30 & 90.9 \\
\cline { 2 - 4 } & Total & 33 & 100.0 \\
\hline
\end{tabular}

The results of the frequency test in table 2 involved 3 students who are college only equivalent to $9.1 \%$, and 30 college students who are also working equivalent to $90.9 \%$, with the Overall study amounting to 33 students. Table 3 shows the validity and reliability of the instrument items in this study.

Table 3. Reliability Statistics

\begin{tabular}{|c|c|c|c|}
\hline Variable & Cronbach's Alpha & No of Items & Description \\
\hline Commitment & $\mathbf{. 8 5 7}$ & 11 & Reliable \\
\hline Satisfaction & $\mathbf{. 6 6 1}$ & 15 & Reliable \\
\hline
\end{tabular}

The results of the reliability test in table 3 indicate the values of Cronbach's alpha from the variables in the commitment (0.857) and Satisfaction (0.861). From the values for the variable commitment, satisfaction is reliable and the reliability is at a high/strong level. Table 4 shows the results of the validity test of the instrument item of the commitment. In the first test, there were two invalid items, and then the second validity test is carried out so that the obtained results are valid, as shown in table 4.
Table 4. Validity Test of the Instrument Item of Commitment

\begin{tabular}{|c|c|c|c|c|}
\hline Item & $\begin{array}{c}\text { Corrected } \\
\text { Item-Total } \\
\text { Correlation }\end{array}$ & r_Statistics $>0.3$ & $\begin{array}{c}\text { Cronbach's } \\
\text { Alpha if Item } \\
\text { Deleted } \\
\end{array}$ & Description \\
\hline Com2 & .514 & \multirow{11}{*}{0.3} & .848 & Valid \\
\hline Com3 & .434 & & .853 & Valid \\
\hline Com4 & .516 & & .847 & Valid \\
\hline Com5 & .554 & & .846 & Valid \\
\hline Com7 & .548 & & .847 & Valid \\
\hline Com8 & .718 & & .832 & Valid \\
\hline Com9 & .728 & & .832 & Valid \\
\hline Com 10 & .408 & & .856 & Valid \\
\hline Com11 & .655 & & .837 & Valid \\
\hline Com12 & .567 & & .843 & Valid \\
\hline Com 13 & .460 & & .851 & Valid \\
\hline
\end{tabular}

The validity test results of the commitment item in table 4 indicate that there are 11 valid items and 2 invalid items in advance, up to 11 items included in the next Test. Table 5 shows the validity test results of the satisfaction instrument.

Table 5. Item-Total Statistics

\begin{tabular}{|c|c|c|c|c|}
\hline Item & $\begin{array}{c}\text { Corrected } \\
\text { Item-Total } \\
\text { Correlation }\end{array}$ & r_Statistics $>0.3$ & $\begin{array}{c}\text { Cronbach's } \\
\text { Alpha if } \\
\text { Item } \\
\text { Deleted }\end{array}$ & Description \\
\hline JS1 & .623 & \multirow{15}{*}{0.3} & .847 & Valid \\
\hline JS2 & .312 & & .862 & Valid \\
\hline JS3 & .556 & & .850 & Valid \\
\hline JS4 & .450 & & .856 & Valid \\
\hline JS6 & .571 & & .849 & Valid \\
\hline JS7 & .565 & & .849 & Valid \\
\hline JS8 & .366 & & .859 & Valid \\
\hline JS9 & .533 & & .852 & Valid \\
\hline JS10 & .358 & & .859 & Valid \\
\hline JS11 & .608 & & .848 & Valid \\
\hline JS12 & .603 & & .848 & Valid \\
\hline JS13 & .690 & & .841 & Valid \\
\hline JS14 & .454 & & .855 & Valid \\
\hline JS15 & .392 & & .858 & Valid \\
\hline JS16 & .452 & & .855 & Valid \\
\hline
\end{tabular}


The first validity test is that 1 item is not valid and then the second validity test is performed. The second validity test result is found for 15 items of overall valid satisfaction. Thus 15 satisfaction items are included in the next Test process. Table 6 shows the test results normality of data.

Table 6. One-Sample Kolmogorov-Smirnov Test

\begin{tabular}{|c|c|c|c|}
\hline \multicolumn{2}{|c|}{} & Commitment & Satisfaction \\
\hline \multirow{2}{*}{$\mathrm{N}$} & 33 & 33 \\
\hline \multirow{2}{*}{$\begin{array}{c}\text { Normal Parameters } \\
\text { a,b }\end{array}$} & Mean & 43.21 & 57.45 \\
\cline { 2 - 4 } & Std. Deviation & 5.611 & 7.233 \\
\hline $\begin{array}{c}\text { Most Extreme } \\
\text { Differences }\end{array}$ & Absolute & .121 & .148 \\
\cline { 2 - 4 } & Positive & .083 & .086 \\
\cline { 2 - 4 } & Negative & -.121 & -.148 \\
\hline \multicolumn{2}{|c|}{ Test Statistic } & .121 & .148 \\
\hline \multicolumn{2}{|c|}{ Asymp. Sig. (2-tailed) } & $\mathbf{. 2 0 0}$ c,d & $\mathbf{. 0 6 6}^{\mathbf{c}}$ \\
\hline
\end{tabular}

The test results of data normality in table 6 indicate that the data in the study are a normal distribution with the level of Asymp.Sig. (2-tailed) commitment (0.200) and Satisfaction $(0.066)>0.05$. Thus the next test can be performed to test correlation. Table 7 shows the correlation test results from research conducted in the STIE Galileo environment to students.

Table 7. Correlations

\begin{tabular}{|c|c|c|c|}
\hline \multicolumn{2}{|c|}{} & Commitment & Satisfaction \\
\hline \multirow{3}{*}{ Commitment } & Pearson Correlation & 1 & $\mathbf{. 8 2 1}^{* *}$ \\
\cline { 2 - 4 } & Sig. (2-tailed) & & .000 \\
\cline { 2 - 4 } & $\mathrm{N}$ & 33 & 33 \\
\hline \multirow{3}{*}{ Satisfaction } & Pearson Correlation & $\mathbf{. 8 2 1}^{* *}$ & 1 \\
\cline { 2 - 4 } & Sig. (2-tailed) & .000 & \\
\cline { 2 - 4 } & $\mathrm{N}$ & 33 & 33 \\
\hline
\end{tabular}

**. Correlation is significant at the 0.01 level (2-tailed).

Results showed that there is a positive and significant correlation between commitment and satisfaction. The magnitude of the relationship (0.821) shows that the level of the relationship is in a strong category (Jacob Cohen, 1988). The Research findings support research conducted by (Adekola, 2012; Rageb et al., 2013). The strong relationship shows that the student's commitment to the learning needs to be considered concerning students' learning satisfaction in the circled STIE Galileo Batam. Students' commitment, willingness and the desire to survive and continuity to learn and to be in STIE Galileo are related to the satisfaction of students' learning that can be seen from students' willness for how to enjoy and like the lesson. It is expressed with a sense of the comfortable and positive relationship between fellow students, lecturers, and staff residing in the environment of STIE Galileo.

\section{Summary}

Based on the results of this study, the following can be concluded:

I. Correlation test results show that commitment and satisfaction are positively and significantly correlated. The commitment and satisfaction of student learning in the environment of STIE Galileo contributes positively to the institutions in encouraging the achievement of organizational objectives. Therefore, members must pay attention to commitment and satisfaction, but it is also necessary to consider other variables that are not investigated in this study, such as motivation, environment, and others.

II. For future research, It is recommended to investigate with a more significant number of samples and other analytical tools such as; SEM Smart PLS and SEM Amos. In addition, for future researchers, it is proposed to review again from a demographic standpoint.

\section{Acknowledgements}

The authors thank Program for overseas seminar Assistance, General Directorate of Research and Development Strengthening, Ministry of Research, Technology and Higher Education of the Republic of Indonesia (Kemristekdikti), Dr. Realize, the Friends of faculty STIE Galileo, UTHM, and UTM.

\section{REFERENCES}

[1] Adekola, B. (2012). The Impact of Organizational Commitment on Job Satisfaction: A Study of Employees at Nigerian Universities. International Journal of Human Resource Studies, 2(2), 1-17. https://doi.org/10.5296/ijhrs. $\mathrm{v} 2 \mathrm{i} 2.1740$

[2] Elangovan, A. R. (2001). Causal ordering of stress, satisfaction and commitment, and intention to quit: A structural equation analysis. Leadership \& Organization Development Journal, 22(4), 159-165. https://doi.org/10.1108/01437730110395051

[3] Fard, P. G., \& Karimi, F. (2015). The Relationship between Organizational Trust and Organizational Silence with Job Satisfaction and Organizational Commitment of the Employees of University. International Education Studies, 8(11), 219. https://doi.org/10.5539/ies.v8n11p219

[4] Hani Handoko. (2010). Manajemen Personalia \& Sumberdaya Manusia. Yogyakarta: BPFE UGM.

[5] Hasibuan, M. S. P. (2012). Manajemen Sumber Daya Manusia (Ke enam be). Jakarta: PT Bumi Aksara. 
[6] Hazriyanto, \& Ibrahim, B. (2019). The Factor Analysis of Organizational Commitment, Job Satisfaction, and Performance among Lecturers in Batam. Journal of Technical Education and Training, 11(1), 151-158. https://doi.org/https://doi.org/10.30880/jtet.2019.11.01.19

[7] Jacob Cohen. (1988). Statistical Power Analysis for The Behavioral Sciences. In Lawrence Erlbaum Associates. New York.

[8] Luthans \& F. (2005). Organizational behavior. New York: McGraw-Hill Irwin.

[9] Mathis, R. L., \& Jackson, J. H. (2011). Manajemen Sumber Daya Manusia (1st ed.). Jakarta: Salemba Empat.

[10] Rageb, M. A., Abd, E. M.-E.-S., El-Samadicy, A., \& Farid, S. (2013). Organizational commitment, job satisfaction and job performance as a mediator between role stressors and turnover intentions a study from an Egyptian cultural perspective. The Business \& Management Review, 3(2), 5173. https://doi.org/10.1108/02683940210428074 